\title{
From the Knowledge of Biology to the use of Animal Model
}

\author{
Jean-Marie Exbrayat* \\ Biologie Générale-Reproduction at Développement Comparé, Catholic University of Lyon, France
}

Submission: December 12, 2016; Published: February 27, 2017

"Corresponding author: Jean-Marie Exbrayat, Biologie Générale-Reproduction at Développement Comparé, Catholic University of Lyon, 10 Place des Archives, 69002 Lyon, France, Email: jmexbrayat@univ-catholyon.fr

Abstract

Since the first representations of animals on the rocky walls, zoology has evolved gradually until today, linked to the evolution of both techniques and concepts. The interest for animal biology may be divided into the knowledge of animal life history and the direct or indirect use of animal for several purposes. Whatever the interest, the basis remains the knowledge of species. The knowledge can be obtained by studying living animals, in respect with legislation, and by studying the collections.

\section{Introduction}

Humans have always been interested in animals. In the Paleolithic, several animals were drawn on the walls of caves with details showing the acute sense of observation of draughtsman. Among the ancient great civilizations, the Egyptians had already solid notions of anatomy and biology. In Mesopotamia, more than 2000 years ago, lists of living forms were engraved on tablets. From a long time man felt the need to recognize living forms, especially animals, and to classify them with certainly utilitarian and religious concern, some animals representing divinities endowed with magical powers.During Antiquity Aristotle (384322 BC) knew about 400 animal species which he classified inenaimaor red-blooded animals, and anaima, devoid of blood, corresponding approximately to vertebrates and invertebrates [1].

Zoology has long been concerned both with real and fabulous animals [2], and became truly scientific at the $17^{\text {th }}$ century's ome large exploration trips increased the number of known species, the permissible practice of dissection contributed to specify the anatomical knowledge, and the invention of the microscope made possible to apprehend the invisible world. In the eighteenth century there appeared some rational explanations of nature. Linnaeus (1707-1778) clarified the notion of species and developed nomenclature principles being always used. Buffon (1707-1788) described the animals by specifying biological data. At the end of the $18^{\text {th }}$ century and beginning of the $19^{\text {th }}$, the comparative anatomy made possible to search common characters between living beings (Cuvier, 1769-1832). The theory of evolution thus saw the light with
Lamarck (1744-1829), then Darwin (1809-1882). In the late nineteenth and twentieth centuries, zoology, which became animal biology, developed.

To-day, the study of animal biology can be divided into three main areas: knowledge of the natural history of species, direct use of animals in nature and indirect use of animals for research purposes.

\section{Animal and Natural Environment}

The question of the reduction of biodiversity is topical, reinforced by the to-day climatic evolution.Several reasons emphasize the importance of knowledge of their biology. The preservation or reintroduction of an animal species requires a solid knowledge of its natural history, which is notalways possible, especially if there is an emergency. Some animals particularly sensitive to the environment such as trichopterabecame indicators of pollution. The effects of toxic molecules have long been sought in various animals. Amphibians, in particular, were the subject of numerous eco-toxicological studies [3]. Nanoparticles in varying concentrations brought into contact with earthworms trigger a program of apoptosis of the cuticle and gastrointestinal tract cells $[4,5]$. Other studies have shown that NPs affected the immune system of invertebrates, triggering oxidative stress. NPs thus exhibit toxic effects related to both their chemical nature and reduced size [6]. A lot of species are regularly infected by parasites [7], and it is necessary to control both the knowledge of the host animal (s) and of the parasite. Some animals may represent "virus reservoirs" that periodically cross the barrier of species to spread to humans. Several animals, 
such as rodents or insects proliferate and destroy crops. Often, the harmful species must be limited but not eradicated because it establishes links with the other species of the biotope in a complex balanced system.

\section{Agriculture, Domestication, Veterinary Science}

Agriculture has always been of great importance in the human economy and the knowledge of animal species contributes to the improvement of animal husbandry, in particular by the choice of genitors and artificial fertilization. Comparable aspects are found in the field of aquaculture. Veterinary science has long been developed on the basis of multiple needs for agriculture but also for transport in peacetime and war.

\section{The Animal-Model}

The animal was often used for physiology studies. Du BoisReymond (1818-1896), Claude Bernard (1813-1878), Pavlov (1849-1936), and Walter Cannon (1871-1945) used mammals, amphibians to understand several aspects of regulation, nervous transmission, and other physiological aspects [8]. To understand the causes of embryonic development, early models were often marine animals such as sea urchins or ascidians, amphibians or chickens, the choice of which meeting both scientific and practical criteria. In order to explain some aspects of development, organ explants were extracted from integrated animals to be cultivated with a culture medium. These experiments were at the origin of animal cell culture [9-11]. Another model, the fly Drosophila melanogaster first used for understanding the laws of genetics by Morgan in the 1910s [12] became a model of choice for approaching molecular embryology. In the natural environment, some animals have pathologies reminiscent of those of the human being. In the nematode Caenorhabditis elegans some strains have mutated genes causing myopathy close to that found in humans [13]. Lemurs show accelerated signs of aging, with behavioral and neurohistological characteristics being those of Alzheimer's disease [14]. The rodent Psammomyso besusis perfectly adapted to life in arid areas. When raised with a rich diet, it becomes obese, with type 2 diabetes and cardio-vascular diseases. So, this rodent is used such as an animal model to study these diseases [15]. Since the 1980s, the use of animal-model has taken on a new dimension with transgenic individuals directly addressing the effects of one or more genes, either by suppressing the latter or by causing them to over express.

\section{Legislation}

Today, in most countries, all the aspects of animal use are submitted to legislation. As a consequence of the decline in biodiversity, legislation requires the presentation of programs to obtain the necessary official governmental authorizations for catching in the field. The evolution of animal perception, involving scientific, societal, political, and philosophical criteria, lead to severe animal testing legislations, that vary from one country to another, requiring the constitution of ethics committees [16,17]. The breeding halls in several countries and particularly in
Europe must meet standard, the staff must be approved to take care of the animals with different levels according to the activity carried out.

\section{Conclusion}

To conclude,the interest for animal is a long story, with different aspects. But whatever the purpose, its basis remains the knowledge of species, indispensable to reach a balance between immediate interests, in the medium and long term. To-day technical means makes possible to examine the rich collections stored in the biobanks of some institutes with powerful methods. Thus, it is possible to study the animals collected by naturalistic travelers of the nineteenth century and even before, bringing additional data useful to the knowledge of the animal.

\section{References}

1. De Wit HCD (1992) Histoire du développement de la biologie. (Vol. I). Presses polytechniques et universitaires romandes, Lausanne p. 404.

2. Pastoureau M (2011) Bestiaires du Moyen-Âge. Seuil Paris, France, pp. 240.

3. Devillers J, Exbrayat JM (1992) Ecotoxicity of chemicals to Amphibians J Devillers (Ed.), Handbooks of ecotoxicological data, Gordon and Breach Science Publishers, Philadelphia, Reading, Paris, Montreux, Tokyo, Melbourne, France, pp. 351.

4. Lapied E, Moudilou E, Exbrayat JM, Oughton DH, Joner EJ (2010) Silver nanoparticle exposure causes apoptotic response in the earthworm Lumbricus terrestris (Oligochaeta), Nanomedicine 5(6): 975-984.

5. Lapied E, Nahami JY, Moudilou E, Chaurand P, Labille J, et al. (2011) Ecotoxicological effects of enaged $\mathrm{TiO}_{2}$ nanocomposite measured as apoptosis in the anecic earthworm Lumbricus terrestris after exposure through water, food and soil, Environment International 37, $1105-1110$

6. Exbrayat JM, Moudilou EN, Lapied E (2015) Harmfuleffects of nanoparticles on animals, Journal of Nanotechnology, Article ID 861092, 1-10.

7. Combes C (2001) L'art d'étre parasite,les associations du vivant. Champs, Flammarion, Paris, France, p.361.

8. Morange M (2016) Une histoire de la biologie. Seuil, Science, Paris, France, pp. 372.

9. Dollander A, Fenard R (1970) Eléments d'embryologie: embryologie générale 1, Flammarion, Paris, p. 366.

10. Dupont JC, Schmitt $S$ (2004) Du feuillet au gène. Edition ENS, rue d'Ulm, Paris, France, pp. 355.

11. Gonzalès J (2012) Histoire de la procréation humaine. Albin Michel, Paris, France, pp. 720

12. Morgan TH (1928)Thetheory of the gene. Yale U.P., New Haven, USA, pp. 309-310.

13. SegalatL, Neri C (2003) C elegans comme modèle pour les maladies dégénératives héréditaires humaines, Médecine et Science 19: 12181225.

14. Verdier JM, Mestre-Frances N, Joly M, Rouland S (2004) Le microcébe, un modéle primate du vieillissement cérébral, Revue Neurologique 160: $962-963$.

15. Khammar F, Gernigon-Spychalowicz T (2004) Le vivant et l'eau: des stratégies pour s'adapter à l'environnement. In : Exbrayat JM, Moreau $\mathrm{P}$ (Eds.), L'Homme méditerranéen et son environnement. Société Linnéenne de Lyon et Université Catholique de Lyon, France, pp. 27-37. 
16. Daneshian M, Busquet F, Hartung T, Leist M (2015) Animal use for science in Europe. ALTEX 32(4): 261-274.

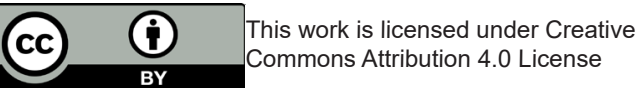

17. M Barek S, Pellevoisin C, Chesné C, Busquet F, Souilem O (2015) First training on alternatives to animal: experimentation in Tunisia. ALTEX 32(4): 388-390

Your next submission with Juniper Publishers will reach you the below assets

- Quality Editorial service

- Swift Peer Review

- Reprints availability

- E-prints Service

- Manuscript Podcast for convenient understanding

- Global attainment for your research

- Manuscript accessibility in different formats

( Pdf, E-pub, Full Text, Audio)

- Unceasing customer service

Track the below URL for one-step submission https://juniperpublishers.com/online-submission.php 